\title{
EUROPEAN SCENARIO STUDIES ON FUTURE IN-STREAM NUTRIENT CONCENTRATIONS
}

\author{
K. Reder, I. Bärlund, A. Voß, E. Kynast, R. Williams, O. Malve, M. Flörke
}

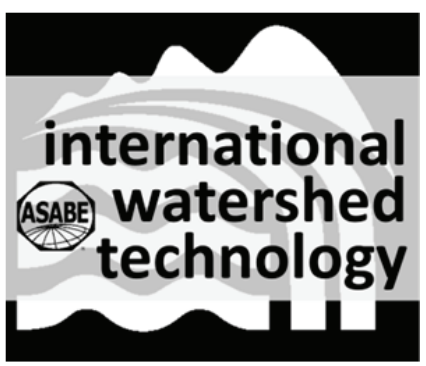

\begin{abstract}
Large-scale water quality issues have recently become the focus of policy and research. To gain insight into large-scale water quality issues, a scenario analysis was carried out for Europe using the continental water quality model WorldQual with total nitrogen and phosphorus as example pollutants. Future nitrogen and phosphorus loadings and instream concentrations were simulated for an "economy first" scenario and compared to contemporary conditions. Results indicate that future total nitrogen (TN) loadings are likely to decrease in most parts of central Europe by 5 to $25 \mathrm{~kg} \mathrm{ha}^{-1}$ year ${ }^{-1}$ due to land-use change in the form of reduced cropland area as a result of technological changes, as well as improvements in land-use management based on higher efficiencies of application rates. Climate change has less impact on $T N$ loadings, but an increase of future in-stream concentrations is accompanied by reduced river discharge. Future total phosphorus (TP) loadings are similar to contemporary loadings for all of Europe. In-stream TP concentrations do not change in northern and eastern Europe. In central Europe, concentrations increase little (by one class). In a few regions, such as northern Spain, very high changes (up to more than three classes) are apparent as a result of reduced river discharge.
\end{abstract}

Keywords. Europe, Large scale, Modeling, Nitrogen, Phosphorus, Water quality.

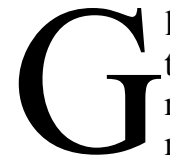
lobal-scale water-related problems are an issue that has frequently been discussed in the area of research and policy during the past decades, mainly focusing on water quantity (Kasten and Khaka, 2009). Knowledge about future global water quantity and its change is essential for many regions in planning their water demands and management. In addition, even if water resources are available, they have to fulfill certain water quality standards to serve their purpose. As water research and water policy issues have gained global significance, there is a need to study water quality issues from a large-scale perspective, which is usually done by taking samples. However, taking samples that cover large regions, such as Europe, is very expensive in time and money. A common way to overcome these issues is to use a model that can identify hotspots of high concentrations. This information is then useful to focus sampling on regions that

Submitted for review in October 2012 as manuscript number SW 9961; approved for publication by the Soil \& Water Division of ASABE in April 2013.

The authors are Klara Reder, Doctoral Student, Center for Environmental Systems Research (CESR), University of Kassel, Kassel, Germany; Ilona Bärlund, Postdoctoral Fellow, Helmholtz Center for Environmental Research (UFZ), Magdeburg, Germany; Anja Voß, Postdoctoral Fellow, and Ellen Kynast, Mathematician, CESR, University of Kassel, Germany; Richard Williams, Principal Scientist, Natural Environment Research Council, Centre for Ecology and Hydrology (NERC-CEH), Wallingford, U.K.; Olli Malve, Postdoctoral Fellow, Finnish Environment Institute (SYKE), Helsinki, Finland; and Martina Flörke, Postdoctoral Fellow, CESR, University of Kassel, Germany. Corresponding author: K. Reder, Wilhelmshöher Allee 47, University of Kassel, 34117 Kassel, Germany; phone: +49-561-804-6123; e-mail: reder@usf.uni-kassel.de. are highly contaminated. However, large-scale water quality modeling is still an issue that has received little attention. While a few large-scale models exist that estimate current and future pollutant loadings (Behrendt et al., 2002; Green et al., 2004; Grizzetti and Bouraoui, 2006; Seitzinger et al., 2002), only Arheimer et al. (2012) calculated in-stream concentrations. The studies by Behrendt et al. (2002), Green et al. (2004), and Grizzetti and Bouraoui (2006) focused on historic and/or contemporary simulations of nutrient loadings and investigated the impact of sources contributing to total nutrient loads in rivers. Green et al. (2004) analyzed the flux of nitrogen loadings toward the river mouth. Seitzinger et al. (2002) compared three different scenarios in order to estimate future nitrogen loadings: a business-as-usual scenario (BAU), a changes in fertilizer use and human diet scenario (DIET), and a change in deposition rates scenario. Results of the BAU scenario were that $\mathrm{N}$ inputs would increase from $21 \mathrm{Tg} \mathrm{N}^{\mathrm{Near}}{ }^{-1}$ in 1990 to 47 Tg $\mathrm{N}_{\text {year }}{ }^{-1}$ in 2050. In the DIET scenario, $\mathrm{N}$ inputs to the north Atlantic Ocean and the Baltic Sea were reduced.

Arheimer et al. (2012) modeled the nitrogen and phosphorous loads and concentrations that reached the Baltic Sea between 1971-2000 and 2071-2100. The authors considered four different climate emission scenarios forcing four different global circulation models (GCMs) and discovered a very high uncertainty within the model ensemble because of the different climate projections. Despite these findings, the nitrogen and phosphorus loadings did not undergo any rapid changes in the scenarios.

At the catchment scale, Bouraoui et al. (2002) analyzed the impact of climate change on nutrient loadings in 2020, 2050, and 2080. They used four, but focused on two, dif- 
ferent climate scenarios and concluded that nutrient loadings increased over the years, but seasonal differences were predominant.

Research at the catchment scale is not limited to Europe. Further studies have investigated the impact of climate change on nutrient loadings, such as Murdoch et al. (2000) in the U.S. and Ngcobo et al. (2012) in South Africa. An extensive review of studies at the catchment scale that analyze the impact of climate change on nutrients can be found in Delpla et al. (2009).

Stakeholders and policymakers in charge of long-term strategic planning of European water resource development are interested in answering complex questions about the future of Europe's freshwater resources, both in quantitative and qualitative terms. In order to estimate future conditions of Europe's freshwater resources, scenarios are needed to describe future climate and socio-economic developments. Thus, in the EU-FP6 project SCENES (Water Scenarios for Europe and for Neighboring States), the "story and simulation" approach was applied to generate a set of comprehensive scenarios up to 2050 in a participatory stakeholder process (Kämäri et al., 2008). Within our study, a modeling framework was set up to assess future impacts of climate and land-use change on future in-stream water quality by considering diffuse and point sources. Both climate and land-use changes are considered important, which is also acknowledged by the IPCC (2003). In its report, the IPCC stated that the load of agricultural inputs is most likely to be affected by climate change because a changing climate may alter agricultural practices.

This article builds on the findings from the SCENES project. We assess changes in total nitrogen and total phosphorous loadings and concentrations in European rivers for the 2050s, taking into account climate and land-use changes. Several model simulations were carried out on the European scale to (1) identify future hotspot regions and (2) analyze the impact of climate and land-use changes with respect to diffuse and point loadings. Within this context, two additional model experiments were carried out to iden- tify the sensitivity of the loadings and the in-stream concentrations to climate and land-use changes.

\section{Material ANd Methods}

\section{THE WORLdQUAL MODEL}

The global model WaterGAP3 comprises three different submodels to simulate current and future conditions of freshwater resources: a hydrology model (Alcamo et al., 2003; Verzano, 2009; Schneider et al., 2011), a water use model (Aus der Beek et al., 2010; Flörke et al., 2013), and the water quality model WorldQual (Malve et al., 2012; Voß et al., 2012; Williams et al., 2012). Figure 1 gives an overview of the model framework and shows the interactions between the three submodels. As this article focuses on water quality issues, only the WorldQual model is described in more detail. WorldQual is a large-scale water quality model that calculates loadings and in-stream concentrations based on the output of the hydrology and water use models. Overall, the model operates on a grid resolution (cell size) of 5 arc minutes and on a monthly basis. In a first step, loadings are accumulated for each grid cell. Within the model, loadings from point and diffuse sources are distinguished. Point sources include domestic sewage, wastewater from manufacturing industries, and urban surface runoff. Diffuse sources comprise agricultural inputs and geogenic background emissions. Additionally, scattered settlements are considered and contribute to both types of sources.

The estimation of point-source loadings is described in detail by Williams et al. (2012). In general, loads from the domestic sector are calculated by multiplying a per capita emission factor by the urban and rural populations connected to sewage treatment plants (STPs). The loads are further reduced depending on the level of wastewater treatment. National values for percentages of primary, secondary, tertiary wastewater treatment of STPs are downscaled to the grid-cell level to define a cell-specific reduction rate. Loads

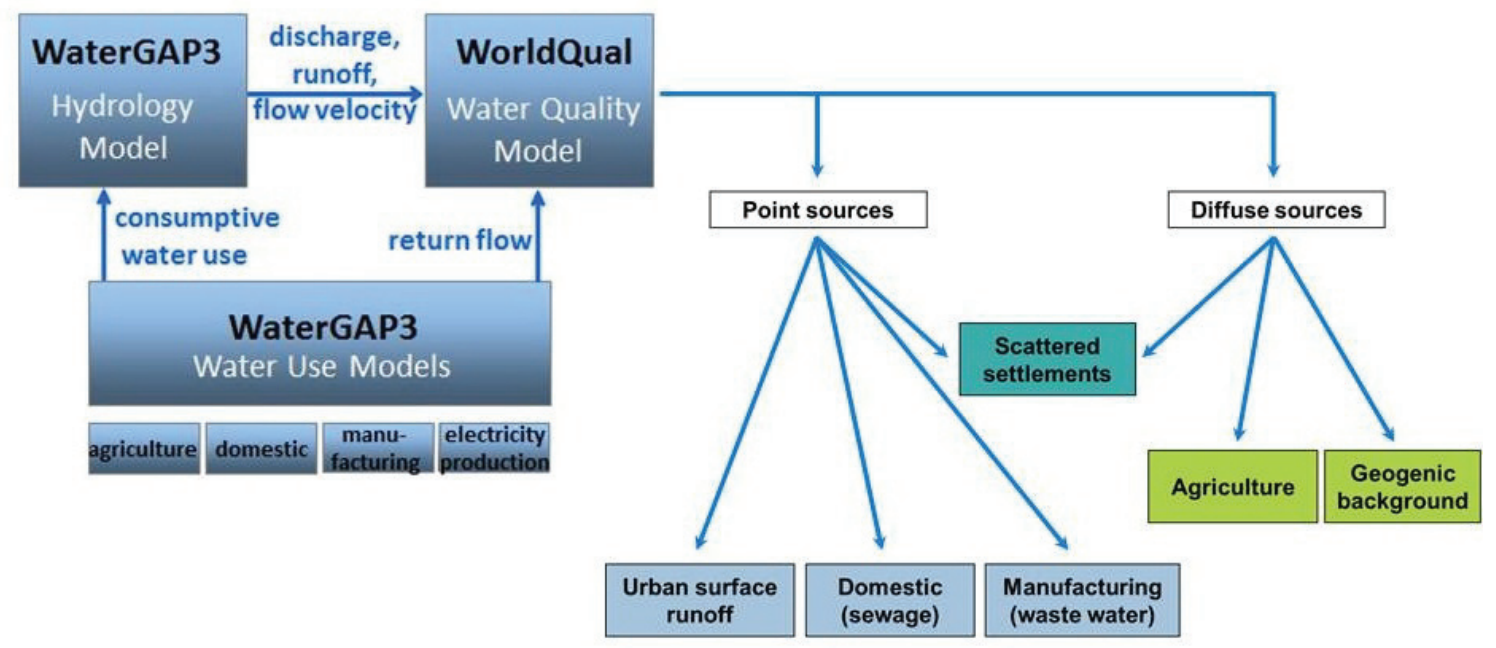

Figure 1. WaterGAP3 with its three submodels: the hydrology model, the water use model, and the water quality model WorldQual. WorldQual distinguishes point sources (domestic and manufacturing wastewater, urban surface runoff, scattered settlements) and diffuse sources (agricultural inputs, geogenic background, scattered settlements). 

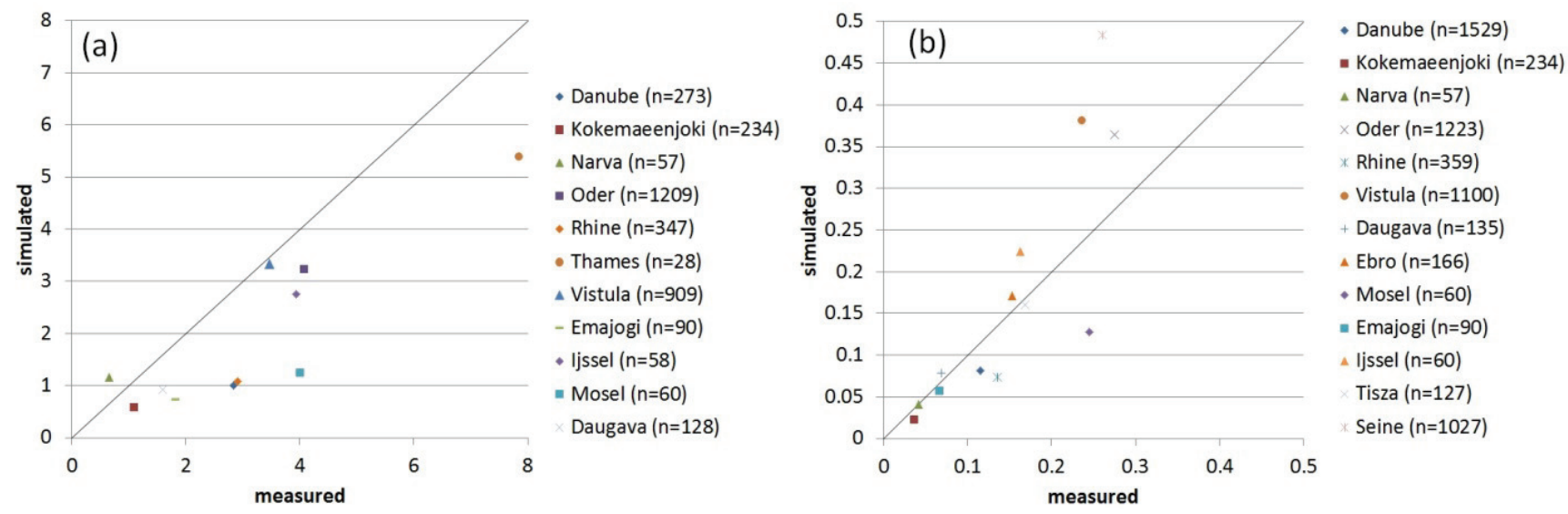

Figure 2. Comparison of measured and simulated five-year average in-stream concentrations for selected European rivers from 1998 to 2002 for (a) total nitrogen and (b) total phosphorus ( $n=$ sample size).

of scattered settlements are calculated like those of the domestic sector, but the approach considers only the share of population not connected to STPs. In this case, a secondary treatment level and the respective reduction rates are assumed. Manufacturing loadings are calculated by the average raw effluent concentration multiplied by the return flow from manufacturing industries. Here again, the manufacturing load is also reduced by a cell-specific reduction factor depending on the treatment level. The urban load is calculated similar to the manufacturing load by multiplying the typical event mean concentration by the urban runoff.

The calculation of diffuse loadings follows the methodology of Malve et al. (2012) in which an export coefficient is estimated by linear regression analysis. For both TN and $\mathrm{TP}$, the runoff, number of livestock, and lake area are part of the regression equation. Additionally, cropland area for $\mathrm{TN}$ and slope for TP were added to this modeling approach. The result of the regression was that changes in runoff have the greatest impact on diffuse loadings.

In a second step, each river segment receives a proportion of the calculated load depending on the river discharge (Voß et al., 2012), which leads to an initial in-stream concentration that is further reduced by a temperaturedependent decay process (Thomann and Mueller, 1987). Grid cell concentrations are routed and accumulated toward the river mouth following a high-resolution drainage direction map (Lehner et al., 2008).

For visualization purposes, the concentrations are divided into seven concentration classes (table 1) that are derived from the chemical classification as elaborated by the German Working Group of the Federal States on Water Issues (LAWA, 2010). We selected this classification system to highlight changes in concentration all over Europe, i.e., mapping very low to very high concentrations. Work-

Table 1. Concentration classes from the LAWA for TN and TP.

\begin{tabular}{ccc}
\hline Class & $\mathrm{TN}\left(\mathrm{mg} \mathrm{L}^{-1}\right)$ & $\mathrm{TP}\left(\mathrm{mg} \mathrm{L}^{-1}\right)$ \\
\hline 1 & $\leq 1$ & $\leq 0.05$ \\
2 & $\leq 1.5$ & $\leq 0.08$ \\
3 & $\leq 3$ & $\leq 0.15$ \\
4 & $\leq 6$ & $\leq 0.3$ \\
5 & $\leq 12$ & $\leq 0.6$ \\
6 & $\leq 24$ & $\leq 1.2$ \\
7 & $>24$ & $>1.2$ \\
\hline
\end{tabular}

ing with absolute or relative changes instead would have resulted in too many classes and too many colors for visualization.

WorldQual was validated for BOD and TDS by Voß et al. (2012) and for TN and TP by Malve et al. (2012). Figure 2 shows the fit of simulated to measured in-stream TN and TP concentrations for several European rivers for the time period 1998 to 2002. Five-year means of measured and simulated in-stream concentrations were chosen because some input data, e.g., connection to STPs, were only available as fiveyear averages. Overall, the model outcomes better represent TP concentrations compared to TN, where the model agreement is slightly lower. TN concentrations are mainly underestimated, especially for the Mosel, Rhine, Danube, and Thames. The simulated in-stream TP concentrations are in good agreement with the measured data, although some rivers are underestimated (Mosel and Rhine) or overestimated (Seine, Oder, and Vistula).

\section{INPUT DATA}

River discharge is the main hydrological input for WorldQual, next to urban runoff and flow velocity. The hydrological input for the baseline as well as future projections was generated as monthly time series with the hydrology model WaterGAP3 (Verzano et al., 2012). Several parameters are necessary to calculate point loads of the base year: per capita emission factors, population density, connection rates to STPs, pollutant-specific removal rates, typical rain event mean concentration, and industrial raw effluent concentration, as described by Williams et al. (2012). To calculate diffuse loads, the river discharge, number of livestock, cropland area, slope steepness, and lake area are presented by Malve et al. (2012). For estimation of instream concentrations, the water temperature, decay rates at $20^{\circ} \mathrm{C}$, and a temperature correction coefficient are mandatory (Malve et al., 2012; Voß et al., 2012). The values for these parameters are stated in the corresponding references.

\section{Climate Data}

For the baseline, the climate input, including monthly information on precipitation and temperature, covered the time period 1961-1990. A combination of the datasets CRU TS 2.1 (Mitchell and Jones, 2005) and CRU TS 1.2 (Mitch- 
ell et al., 2004) was used because the CRU TS 1.2 dataset, which has a higher spatial resolution (10 arc minutes) than CRU TS 2.1 (30 arc minutes), covers only the predominant part of Europe. In order to get information for grid cells that were not covered by CRU TS 1.2, the CRU TS 2.1 dataset was applied. Both datasets were simply downscaled to grid cells of 5 arc minutes. In SCENES, results from two different GCMs were used following the IPCC SRES A2 pathway (Nakicenovic and Swart, 2000) in order to take climate change into account. The analysis presented here considered climate data from only one GCM. We selected the climate forcing from the IPSL-CM4 model from the Institute Pierre Simon Laplace, France (Hourdin et al., 2006; Madec et al., 1998; Fichefet and Morales Maqueda, 1997; Goosse and Fichefet, 1999), indicating high temperature increase together with low change in precipitation (increase or decrease) over large parts of Europe. Future climate projections are produced for WaterGAP3 by scaling a standard gridded dataset of mean monthly precipitation and temperature from the CRU time series with the differences between current and future conditions as computed by the climate models (delta change approach, e.g., Henrichs and Kaspar, 2001; Lehner et al., 2006). Air temperature data are scaled by addition, and precipitation data are scaled by multiplication. An exception to this rule occurs when present-day precipitation is close to zero $(<1 \mathrm{~mm})$; in that case, the respective precipitation rise is added.

\section{SCENES SOCIO-ECONOMIC AND \\ LAND-USE CHANGE SCENARIOS}

Within SCENES, comprehensive scenarios were developed in a participatory stakeholder process (Kok et al., 2011) and include consistent projections of the main drivers, such as population, GDP, agricultural production, as well as information on technological developments until 2050. In this study, we address the "economy first" (EcF) scenario, which is characterized by a globalized and liberalized economy pushing the use of all available energy sources and accompanied by an agricultural intensification. A further increase of population by $8.5 \%$ (67.5 million people) is projected for Europe between 2005 and 2050 under the EcF scenario, accompanied by economic activity that continues to grow over the whole scenario period, resulting in a twofold growth in GDP. In this scenario, a decrease in agricultural subsidies leads many farmers to abandon their farms where lack of water or infertility of soils makes crop production uneconomical. On the other hand, the demand for food exports leads to an intensification of crop production on the most productive land. At the same time, low water-saving consciousness results in an increased water demand for all water-related sectors.

Future point loads were derived by asking the expert panel to imagine how the model drivers would change for each scenario. The important drivers were per capita emissions, population change, changes in the percentage of the population connected to sewage treatment works, and changes in the effectiveness of sewage treatment. The emission factors were influenced by diet for nitrogen and by removal of phosphorus from detergents used in clothes washing.

Land-use change scenarios were calculated with LandSHIFT (Schaldach et al., 2012) driven by the information obtained during the participatory scenario development process. The baseline land-use map of LandSHIFT is based on the Corine 2000 data base (EEA, 2007) for the EU-27 countries. Land-use data for the remaining European countries were taken from Heistermann (2006), who provided a crop-specific version of the GLCC land-use map.

In addition to the EcF scenario, two more simulation experiments were analyzed: (1) the EcF scenario with baseline climate conditions (EcF_cb), and (2) the EcF scenario with baseline land-use (EcF_lub). With these two experiments, analysis of climate change and land-use impacts is possible.

\section{RESULTS AND DISCUSSION}

Figure 3 illustrates total nitrogen (fig. 3a) and total phosphorus (fig. 3b) loadings for Europe as calculated for the base year (2005). TN loadings are higher in southern, western, and eastern Europe and western Asia, with 10 to $>30 \mathrm{~kg} \mathrm{ha}^{-1}$ year $^{-1}$. Hotspots of TN loading with $>30 \mathrm{~kg} \mathrm{ha}^{-1}$ year ${ }^{-1}$ occur in western Europe. In general, TP loadings are similar over all of Europe, mainly $\leq 1 \mathrm{~kg} \mathrm{ha}^{-1} \mathrm{year}^{-1}$, and only urban areas show point-shaped hotspots up to $>30 \mathrm{~kg}$ ha $^{-1}$ year ${ }^{-1}$.

\section{TOTAL NitRogen}

Figure 4a displays the difference between the baseline (fig 3a) and the EcF scenario for total nitrogen in 2050. The highest increases $\left(>25 \mathrm{~kg} \mathrm{ha}^{-1}\right.$ year $\left.^{-1}\right)$ primarily occur due to changes in the domestic sector. Some areas in the outer parts of Europe also display increased TN loadings of 5 to $25 \mathrm{~kg} \mathrm{ha}^{-1}$ year $^{-1}$ because of changes in the manufacturing sector.

Most evident is that southern, western, and eastern Europe as well as western Asia experience a decrease in TN loadings between 5 and $25 \mathrm{~kg} \mathrm{ha}^{-1}$ year $^{-1}$. This decrease has the following causes. Changes in land-use management according to the EcF scenario mean that nutrient applications are optimized to meet plant uptake to reduce costs, and loss of nutrients is minimized. Additionally, only areas that are economically viable to be cultivated are used for intensified agriculture, and arable land is abandoned where crop production is not economical. Both developments lead to an increase in set-aside areas over large parts of Europe.

Figure $4 \mathrm{~b}$ demonstrates the results of future diffuse nitrogen loadings as absolute changes to the baseline conditions. The main reductions and increases are in the same regions as for TN loadings (fig. 4a). This shows that TN loadings are dominated by diffuse sources resulting from the agricultural sector. Hence, land-use change and improvement in management of agricultural land contribute the most to a change in loadings. 
(a)

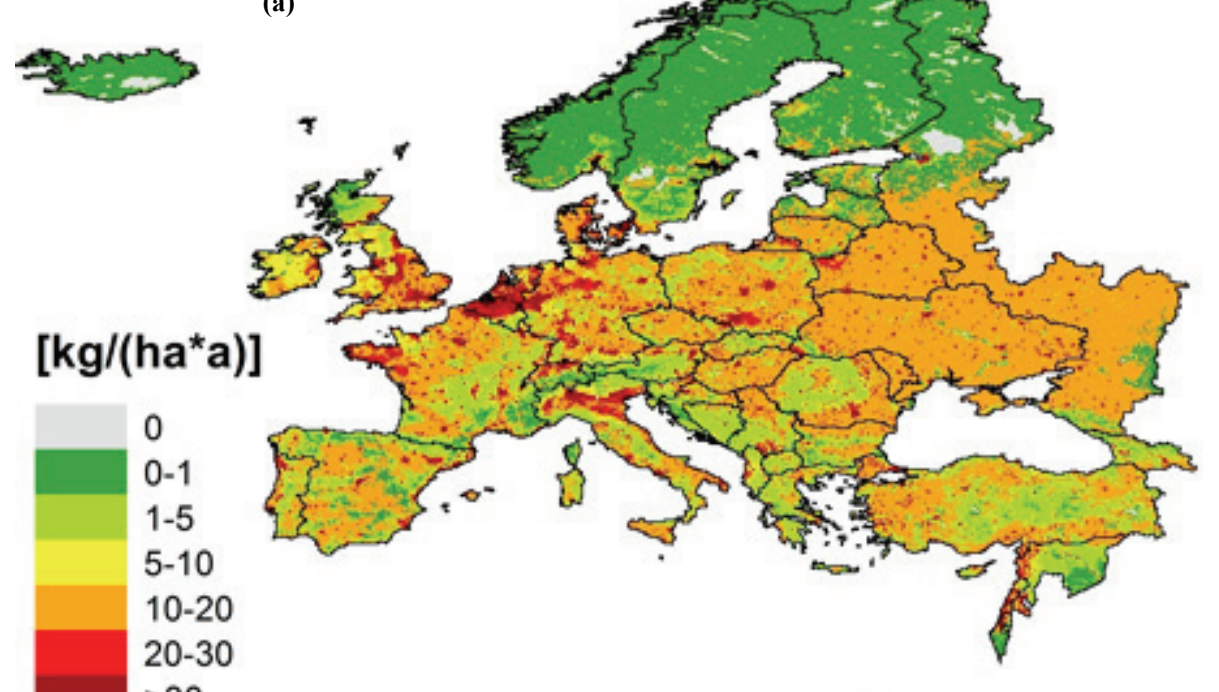

$>30$

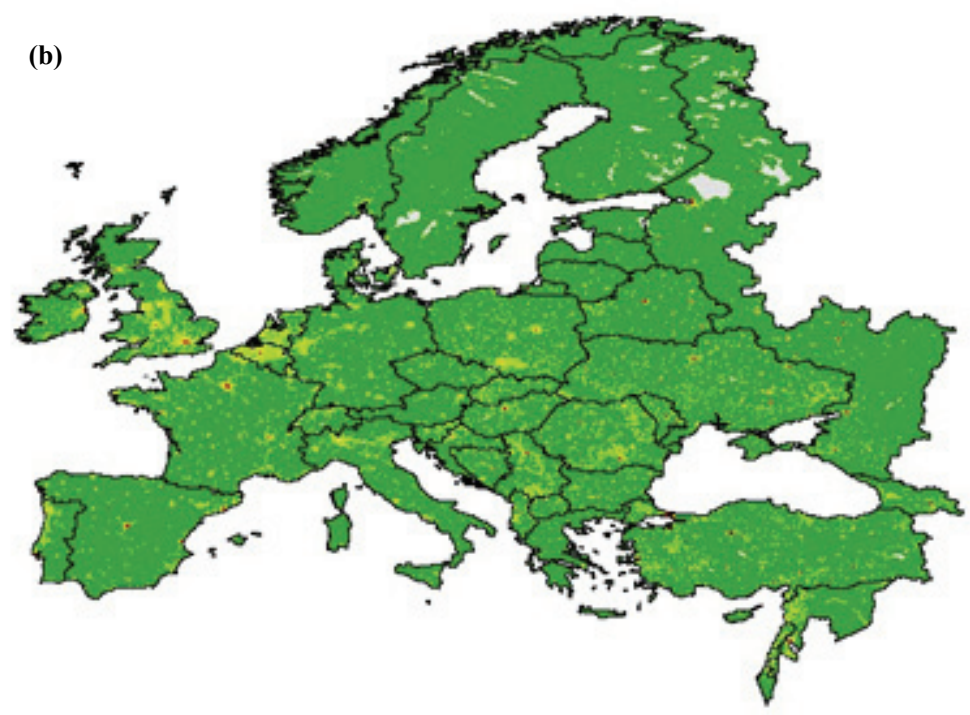

Figure 3. Baseline loading $\left(\mathrm{kg} \mathrm{ha}^{-1}\right.$ year $\left.^{-1}\right)$ in 2005 as calculated at baseline climate (1971-2000) for (a) total nitrogen and (b) total phosphorus.

To analyze the impact of climate change on TN loadings, simulations for the EcF_cb experiment were carried out. The EcF_cb simulation is the same as EcF except for climate, which is kept constant to the baseline (19712000) (fig. 5a). A comparison between EcF_cb and EcF (fig. 4a) does not show any apparent differences, suggesting that, over this time scale, climate change likely has little impact on future nitrogen loadings in this scenario.

The TN loadings show a different spatial distribution when comparing the EcF lub simulation experiment with the EcF scenario (fig. 5b). In contrast to the EcF scenario, the EcF_lub experiment is forced by baseline land-use. The change in loading differs between regions. In northern and central Europe, no changes in loadings compared to the baseline are visible for the 2050s. In eastern Europe and western Asia, loadings are reduced by -5 to $-25 \mathrm{~kg} \mathrm{ha}^{-}$ ${ }^{1}$ year $^{-1}$, which is presumably due to the spread of new technologies, such as wastewater treatment. On the contrary, loadings increase in some areas of western Europe as a result of socio-economic changes in the domestic and manufacturing sectors. Principally, EcF lub caused small changes over most of Europe. This is very different from EcF (fig. 4a), in which central Europe experiences large reductions in future TN loadings. The only difference between these two model experiments is the assumption of land-use changes, suggesting that land-use change has a relatively large impact on the spatial distribution of future TN loadings in this EcF scenario.

This finding is in accordance with the results of the DIET scenario published by Seitzinger et al. (2002). The DIET scenario assumes reductions in human consumption of animal protein, reducing fertilizer use. As a result, nitrogen inputs to the north Atlantic Ocean and the Baltic Sea are reduced by $25 \%$ to $10 \%$ in 2050 compared to the baseline 1990.

Arheimer et al. (2012) investigated the nutrient exports to the Baltic Sea. Results for nitrogen show a slight decrease of loads because of climate change, i.e., higher temperatures increase denitrification. This is similar to our findings, in which climate change does not have a 

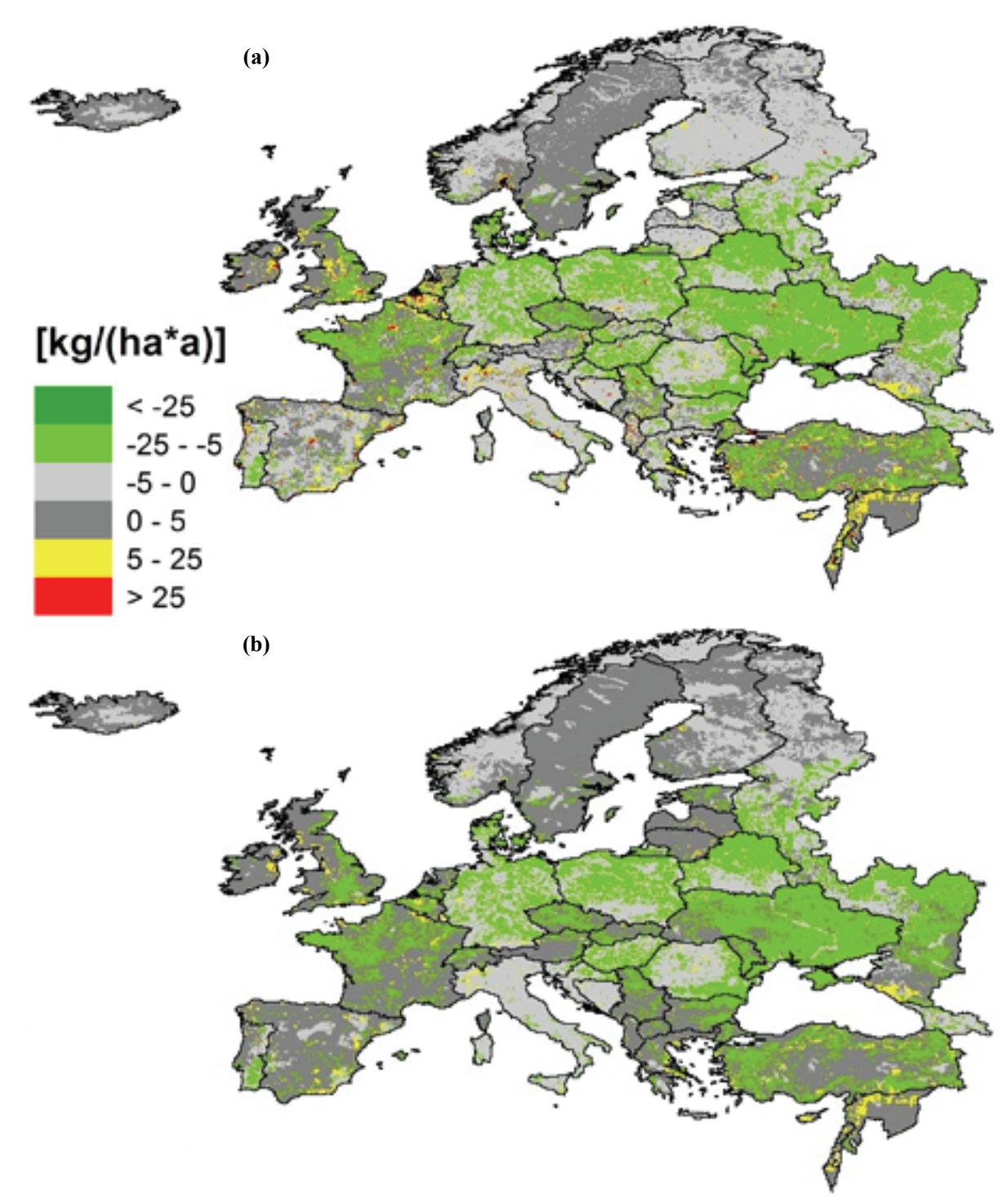

Figure 4. Absolute change $\left(\mathrm{kg} \mathrm{ha}^{-1}\right.$ year $\left.^{-1}\right)$ between the baseline and the future for the EcF scenario and IPCM-A2 climate in 2050 for (a) total nitrogen loading and (b) diffuse nitrogen loading.

great impact on future TN loadings. Furthermore, Arheimer et al. (2012) analyzed the impact of combined remedial measures and climate change and found out that future nitrogen loads would decrease due to a reduction in diffuse pollution from arable land. Both findings are analogous to our findings.

Bouraoui et al. (2002) studied the catchment of the River Ouse in northern England. They found an increase of total nitrogen loadings on an annual basis, which is contrary to our results for the same river basin. The results of Bouraoui et al. (2002) are solely attributed to the impact of climate change, whereas in our study, socioeconomic and land-use changes are also part of the scenario. Moreover, socio-economic and land-use changes cause a respective decrease in total nitrogen in the future. Consequently, it is necessary to investigate not only the impact of climate change but also the socio-economic and land-use changes.
Future TN concentrations develop differently from TN loadings. TN loadings decrease, whereas TN concentrations increase or stay the same for large areas in Europe. TN concentrations increase in southern Europe and western Asia in January and in the same regions including western Europe in July. In July, changes in concentration class from +1 to $>3$ are more pronounced than in January as a result of dilution effects. This is in accordance with Arheimer et al. (2012), who described a decrease in concentrations in winter due to dilution effects. In-stream concentrations are higher during summer when river discharge is low, in particular in southern Europe. This leads to the conclusion that, even with reduced TN loadings, instream concentrations can increase because of reduced river discharge.

\section{TOTAL Phosphorus}

Total phosphorus loadings in 2050 show no area-wide changes but rather point-shaped changes. Hotspots appear 
(a)
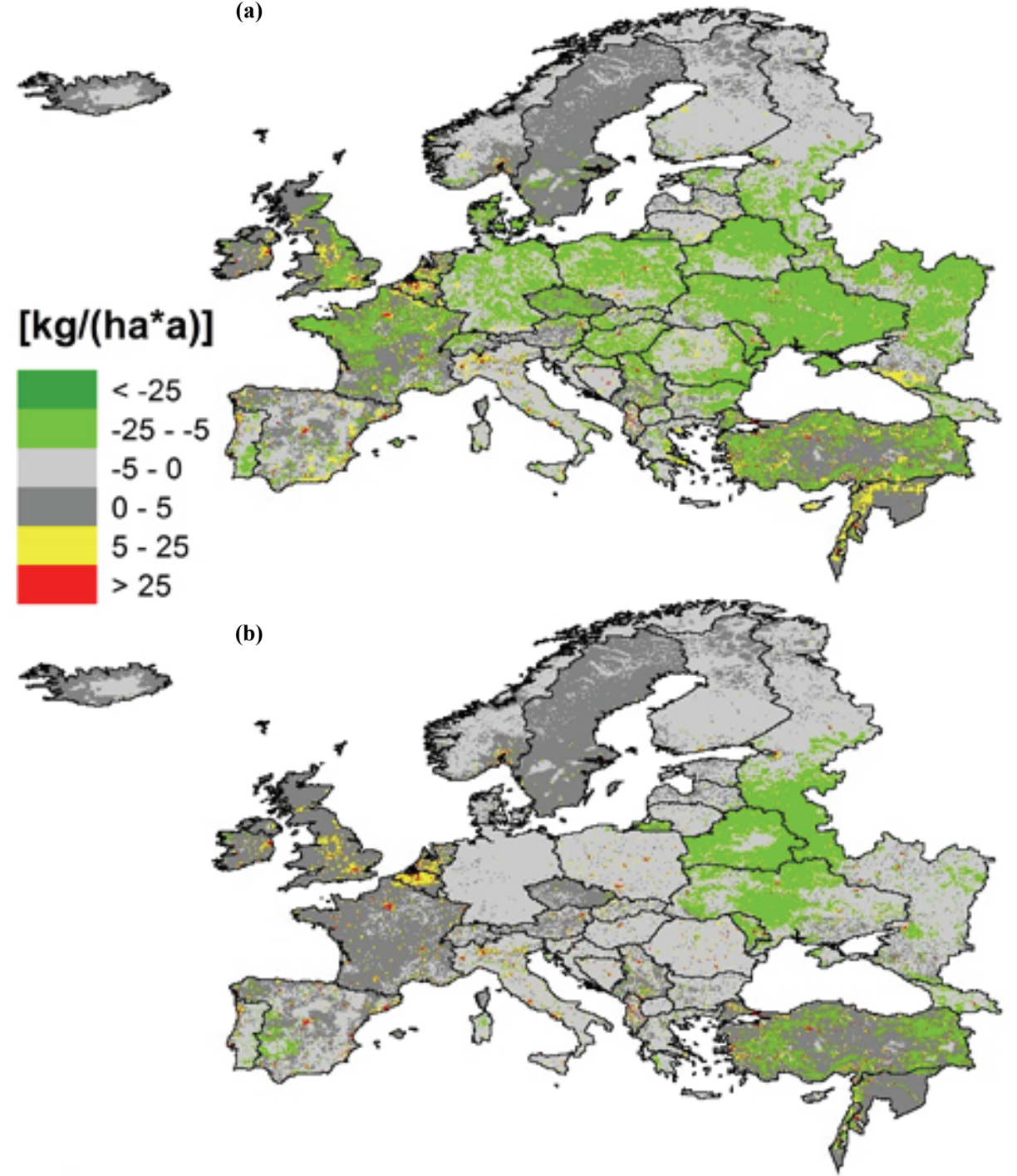

Figure 5. Absolute change ( $\mathrm{kg} \mathrm{ha}^{-1}$ year $\left.^{-1}\right)$ in TN loading between the baseline and future for the EcF scenario and IPCM-A2 climate in 2050 for (a) EcF_cb (baseline climate) and (b) EcF_lub (baseline land-use and IPCM4-A2 climate).

mainly due to increases related to changes in the domestic and manufacturing sectors. A few spots where TP loadings decrease appear in southeastern Europe due to a decrease in scattered settlements.

In figure $6 \mathrm{a}$, the baseline in-stream concentrations are displayed for TP in concentration classes 1 (lowest) to 7 (highest) (table 1). Concentrations increase from northern Europe to southern Europe due to the following factors. First, agricultural areas are less widespread in the north compared to southern Europe. Second, water resources in southern Europe are scarce due to high temperatures, and thus higher evaporation, as well as lower precipitation.

Figure $6 \mathrm{~b}$ displays the differences between the TP concentration classes and the baseline for the EcF 2050 scenario. Changes in western and southern Europe predominate, with increased concentrations and concentration class changes from +1 to $>+3$ classes. In these regions, some rivers feature large concentrations class changes $(>+3)$ as a consequence of reduced river discharge caused mainly by high temperatures and, therefore, increased evaporation (Schneider et al., 2011). In northern and eastern Europe, in-stream concentrations do not change compared to the baseline.

The EcF_cb and EcF lub simulation experiments were used to analyze the effect of climate change and land-use changes separately. Figure 7 a shows the changes in concentration classes for TP in the EcF cb simulation experiment in 2050. The EcF_cb simulation is the same as EcF (fig. 6b), but the climate is kept constant to the baseline conditions. Our model results show hotspots in western Europe and western Asia. However, areas in eastern Europe and some parts in southern Europe have a negative change in classes of -1 , which implies an improvement of water quality. This differs from the EcF scenario (fig. 6b), where little improvement in water quality occurs. It is apparent that a warm and dry climate has a great influence on the future development of in-stream concentrations. As demonstrated by our results, a warmer and drier climate leads to reduced river discharge, which in turn results in higher concentrations due to less dilution effect. Concen- 
(a)

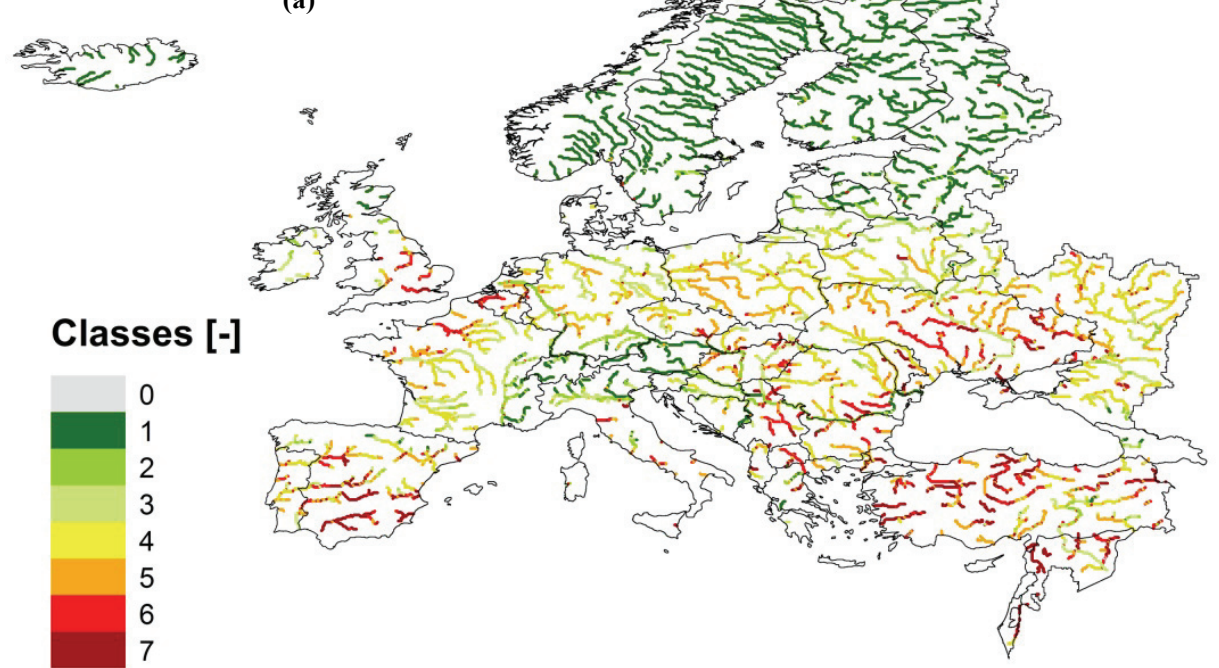

(b)
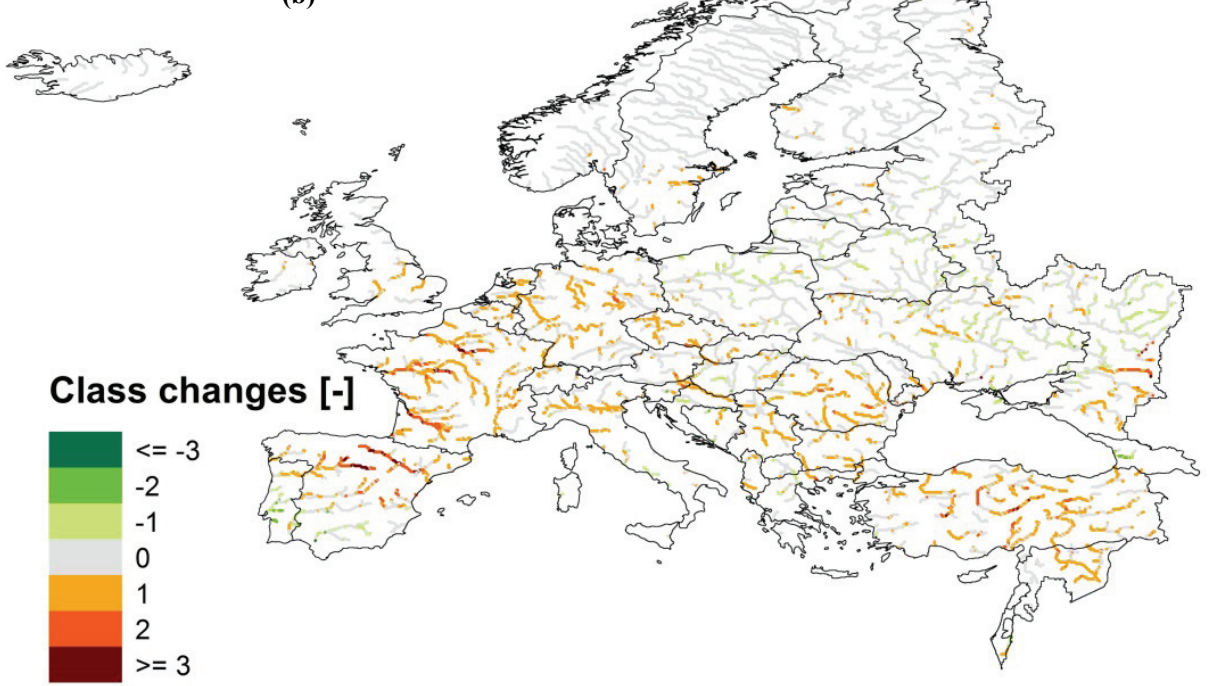

Figure 6. In-stream TP concentration displayed by class change for (a) the baseline in July 2005 and (b) the absolute change in July in the 2050s for the EcF scenario and IPCM4-A2 climate.

trations vary within a year, primarily due to the variation of river discharge, whereas the range of variation depends on the geographic region. Main interannual differences in concentrations can be found in southern parts of Europe, where river discharge is low during summer. Generally, the simulated concentrations are lowest in January and highest in July.

The outcomes of the EcF_lub simulation experiment for TP concentration classes compared to the baseline is shown in figure $7 \mathrm{~b}$. This simulation experiment is the same as EcF (fig. 6b) apart from the land-use changes, which correspond to the baseline values. In analyzing the differences between EcF (fig. 6b) and EcF lub, in some areas the water quality improves compared to the baseline. However, this improvement is less evident than in EcF_cb, where the climate sensitivity was evaluated. This leads to the conclusion that land-use change affects instream concentration, but the effects are not as intense as climate change impacts.

Arheimer et al. (2012) found that phosphorus concentrations decrease slightly in winter and increase slightly in summer. These findings are not consistent with the results of our study for the basins draining into the Baltic Sea, where in-stream concentrations stay the same or slightly decrease in summer. Arheimer et al. (2012) considered climate change and remedial measures of STPs in order to estimate future concentrations. One of their main findings was that remedial measures are most efficient for reducing phosphorus. This, in turn, is in agreement with our outcomes of slight decrease to no change, as remedial measures are analogous to socio-economic changes. 
(a)

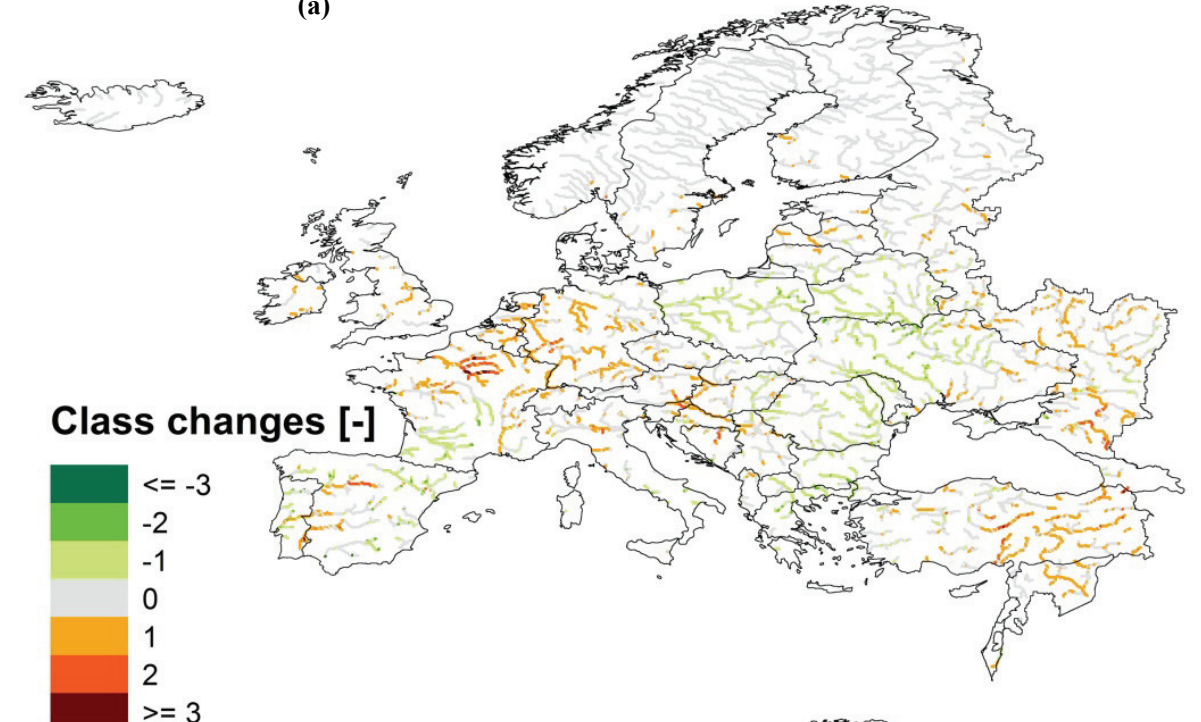

(b)
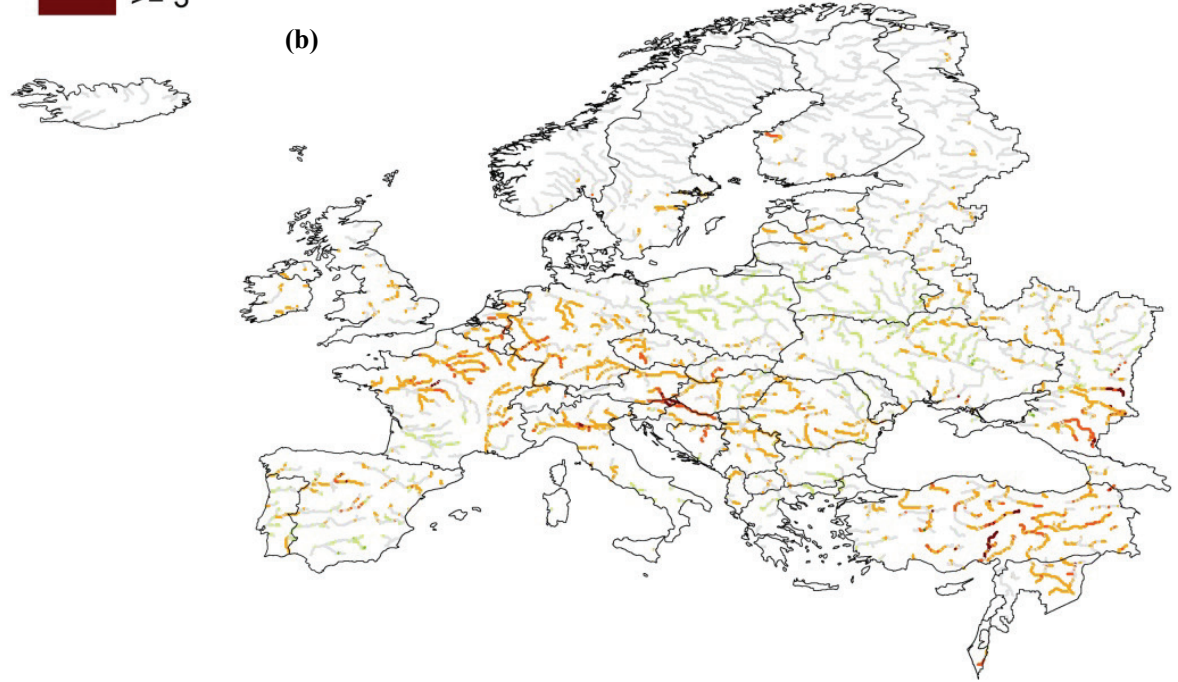

Figure 7. In-stream TP concentration displayed by class change in July in the 2050s for (a) EcF_cb (baseline climate) and (b) EcF_lub (baseline land-use and IPCM4-A2 climate).

\section{CONCLUSION}

This scenario analysis was intended to show future loading and in-stream concentration of nutrients in Europe, which was accomplished with the model WorldQual. A decrease or increase in nutrient loading does not necessarily result in similar changes in nutrient in-stream concentrations. In-stream concentrations may change in the opposite direction depending on the river discharge. Future TN loadings are expected to decrease in southern, western, and eastern Europe and western Asia, but are likely to remain the same in most parts of northern Europe. This is mainly due to land-use change and improvements in land-use management. While climate change up to 2050 does not show large impacts on future TN loadings, it does show impacts on in-stream TN concentrations. This results from reduced river discharge. Future TP loadings are expected to increase primarily from the domestic and manufacturing sectors all over Europe. Apart from these two sectors, there will be no change in TP loadings. Between now and 2050, in-stream TP concentra- tions are likely to increase in western and southern Europe and western Asia due to reduced river discharge driven by climate change in the form of higher temperatures leading to increased evaporation. Land-use change shows little influence on future in-stream TP concentrations.

WorldQual is still in the first phase of development; therefore, the scenario analysis and simulation experiments are part of an effort to gain insight into the way the model works and its ability to assess scenarios. Further research could improve the model's structure and expand the model's application. This could include transfer to other geographical regions, such as North America, and adding further water quality parameters, such as fecal coliforms.

\section{ACKNOWLEDGeMENTS}

The authors thank all the contributors for data made available by the SCENES project under Contract No. 036822. We also gratefully acknowledge the reviewers for their helpful comments and suggestions for the manuscript. 


\section{REFERENCES}

Alcamo, J., P. Döll, T. Heinrichs, F. Kaspar, B. Lehner, T. Rösch, and S. Siebert. 2003. Development and testing of the WaterGAP2 global model of water use and availability. Hydrol. Sci. J. 48(3): 317-337.

Arheimer, B., J. Dahné, and C. Donnelly. 2012. Climate change impact on riverine nutrient load and land-based remedial measures of the Baltic Sea. Ambio 41(6): 600-612.

Aus der Beek, T., M. Flörke, D. M. Lapola, and R. Schaldach. 2010. Modelling historical and current irrigation water demand on the continental scale: Europe. Adv. in Geosci. 27: 79-85.

Behrendt, H., M. Kornmilch, D. Opitz, O. Schmoll, and G. Scholz. 2002. Estimation of the nutrient inputs into river systems: Experiences from German rivers. Regional Environ. Change 3(1-3): 107-117.

Bouraoui, F., L. Galbiati, and G. Bidoglio. 2002. Climate change impacts on nutrient loads in the Yorkshire Ouse catchment (UK). Hydrol. and Earth System Sci. 6(2): 197-209.

Delpla, I., A.-V. Jung, E. Baures, M. Clement, and O. Thomas. 2009. Impacts of climate change on surface water quality in relation to drinking water production. Environ. Intl. 35(8): 12251233.

EEA. 2007. Corine land cover 2000: Mapping a decade of change. Brochure No. 4/2004. Copenhagen, Denmark: European Environment Agency. Available at: www.eea.europa.eu/dataand-maps/data/corine-land-cover-2000-clc2000-250-m-version9-2007.

Fichefet, T., and M. A. Morales Maqueda. 1997. Sensitivity of a global sea ice model to the treatment of ice thermodynamics and dynamics. J. Geophys. Res. 102(C6): 12609-12646.

Flörke, M., E. Kynast, I. Bärlund, S. Eisner, F. Wimmer, and J. Alcamo. 2013. Domestic and industrial water uses of the past 60 years as a mirror of socio-economic development: A global simulation study. Global Environ. Change 23(1): 144-156.

Goosse, H., and T. Fichefet. 1999. Importance of ice-ocean interactions for the global ocean circulation: A model study. $J$. Geophys. Res. 104(C10): 23337-23355.

Green, P. A., C. J. Vörösmarty, M. Meybeck, J. N. Galloway, B. J. Peterson, and E. W. Boyer. 2004. Pre-industrial and contemporary fluxes of nitrogen through rivers: A global assessment based on typology. Biogeochem. 68(1): 71-105.

Grizzetti, B., and F. Bouraoui. 2006. Assessment of nitrogen and phosphorus environmental pressure at European scale. EUR 22526 EN. Ispra, Italy: European Commission, Institute for Environment and Sustainability.

Heistermann, M. 2006. Modeling the global dynamics of rainfed and irrigated croplands. Berichte zur Erdsystemforschung 37. Hamburg, Germany: Max Planck Institute for Meteorology.

Henrichs, T., and F. Kaspar. 2001. Baseline-A: A reference scenario of global change. In EuroWasser: Model-Based Assessment of European Water Resources and Hydrology in the Face of Global Change, 4-1 to 4-8. Kassel World Water Series Report 5. Kassel, Germany: University of Kassel, Center for Environmental Systems Research.

Hourdin, F., I. Musat, S. Bony, P. Braconnot, F. Codron, J.-L. Dufresne, L. Fairhead, M.-A. Filiberti, P. Friedlingstein, J.-Y, Grandpeix, G. Krinner, P. LeVan, Z.-X. Li, and F. Lott. 2006. The LMDZ4 general circulation model: Climate performance and sensitivity to parametrized physics with emphasis on tropical convection. Climate Dyn. 27(7-8): 787-813.

IPCC. 2003. Section 4.3.10: Water Quality. In IPCC Third Assessment Report - Climate Change 2001; Working Group II: Impacts, Adaptation and Vulnerability, 207-208. Geneva, Switzerland: Intergovernmental Panel on Climate Change.

Kämäri, J., J. Alcamo, I. Bärlund, H. Duel, F. Farquharson, M. Flörke, M. Fry, H. Houghton-Carr, P. Kabat, M. Kaljonen, K.
Kok, K. S. Meijer, S. Rekolainen, J. Sendzimir, R. Varjopuro, and N. Villars. 2008. Envisioning the future of water in Europe: The SCENES project. Hennef, Germany: European Water Association.

Kasten, T., and E. Khaka. 2009. Quality matters as much as quantity. Asian Water 25(6): 28-30.

Kok, K., M. van Vliet, I. Bärlund, A. Dubel, and J. Sendzimir. 2011. Combining participative backcasting and explorative scenario development: Experiences from the SCENES project. Tech. Forecasting and Social Change 78(5): 835-851.

LAWA. 2010. Chemische Gewässerklassifikation nach LAWA. Dessau-Roßlau, Germany: Umweltbundesamt, Länderarbeitsgemeinschaft Wasser. Available at: www.umwelt bundesamt.de. Accessed 2 March 2012.

Lehner, B., P. Döll, J. M. Alcamo, T. Henrichs, and F. Kaspar. 2006. Estimating the impact of global change on flood and drought risks in Europe: A continental, integrated analysis. Climatic Change 75(3): 273-299.

Lehner, B., K. Verdin, and A. Jarvis. 2008. New global hydrography derived from spaceborne elevation data. Eos, Trans. $A G U$ 89(10): 93-94.

Madec, G., P. Delecluse, M. Imbard, and C. Lévy. 1998. OPA 8.1: Ocean General Circulation Model Reference Manual. Institut Pierre Simon Laplace: Notes du Pôle de Modélisation, Note No. 11. Available from: Université Paris, Laboratoire d'Océanographie Dynamique et de Climatologie, Paris, France.

Malve, O., S. Tattari, J. Riihimäki, E. Jaakkola, A. Voß, R. Williams, and I. Bärlund. 2012. Estimation of diffuse pollution loads in Europe for continental-scale modelling of loads and in-stream river water quality. Hydrol. Proc. 26(16): 2385-2394.

Mitchell, T. D., and P. D. Jones. 2005. An improved method of constructing a database of monthly climate observations and associated high-resolution grids. Intl. J. Climatol. 25(6): $693-$ 712.

Mitchell, T. D., T. R. Carter, P. D. Jones, M. Hulme, and M. New. 2004. A comprehensive set of high-resolution grids of monthly climate for Europe and the globe: The observed record (19012000) and 16 scenarios (2001-2100). Working Paper 55. Norwich, U.K.: Tyndall Centre for Climate Change Research.

Murdoch, P. S., J. S. Baron, and T. L. Miller. 2000. Potential effects of climate change on surface water quality in North America. $J$. American Water Resources Assoc. 36(2): 347-366.

Nakicenovic, N., and R. Swart, eds. 2000. Emissions Scenarios: Special Report of Working Group III of the Intergovernmental Panel on Climate Change. Cambridge, U.K.: Cambridge University Press. Available at: www.ipcc.ch/ipccreports/sres/ emission/index.htm. Accessed 15 December 2010.

Ngcobo, S., T. G. Lumsden, S. A. Lorentz, G. P. W. Jewitt, and S. Stuart-Hill. 2012. Projected impacts of climate change on water quality and implications for adaptation. In Proc. 16th SANCIAHS National Hydrology Symposium. Pretoria, South Africa: University of Pretoria.

Schaldach, R., J. Koch, T. aus der Beek, E. Kynast, and M. Flörke. 2012. Current and future irrigation water requirements in panEurope: A comparative analysis of influencing factors. Global and Planetary Change 94-95: 33-45.

Schneider, C., F. Flörke, G. Geerling, H. Duel, M. Grygoruk, and T. Okruzko. 2011. The future of European floodplain wetlands under a changing climate. J. Water and Climate Change 2(2-3): 106-122.

Seitzinger, S. P., C. Kroeze, A. F. Bouwman, N. Caraco, E. Dentener, and R. V. Styles. 2002. Global patterns of dissolved inorganic and particulate nitrogen inputs to coastal systems: Recent conditions and future projections. Estuaries 25(4): 640655.

Thomann, R., and J. Mueller. 1987. Principles of Surface Water 
Quality Modeling and Control. New York, N.Y.: Harper Collins. Verzano, K. 2009. Climate change impacts on flood-related

hydrological processes: Further development and application of a global-scale hydrological model. PhD diss. Kassel, Germany:

University of Kassel, International Max Planck Research School on Earth System Modeling.

Verzano, K., I. Bärlund, M. Flörke, B. Lehner, E. Kynast, and F. Voß. 2012. Modeling variable river flow velocity on continental scale: Current situation and climate change impacts in Europe. $J$.
Hydrol. 424-425: 238-251.

Voß, A., J. Alcamo, I. Bärlund, F. Voß, E. Kynast, R. Williams, and O. Malve. 2012. Continental-scale modeling of in-stream river water quality: A report on methodology, test runs, and scenario application. Hydrol. Proc. 26(16): 2370-2384.

Williams, R., V. Keller, A. Voß, I. Bärlund, O. Malve, J. Riihimäki, S. Tattari, and J. Alcamo. 2012. Assessment of current water pollution loads in Europe: Estimation of gridded loads for use in global water quality models. Hydrol. Proc. 26(16): 2395-2410. 